\title{
Antibodies against rickettsiae from spotted fever groups in horses from two mesoregions in the state of Santa Catarina, Brazil
}

[Anticorpos contra rickettsias do grupo da febre maculosa em equinos de duas mesorregiões de Santa Catarina, Brasil]

\author{
A.P. Medeiros ${ }^{1}$, A.B. Moura ${ }^{1 *}$, A.P. Souza ${ }^{1}$, V. Bellato ${ }^{1}$, A.A. Sartor ${ }^{1}$, A. Vieira-Neto ${ }^{1}$, \\ J. Moraes-Filho ${ }^{2}$, M.B. Labruna ${ }^{2}$ \\ ${ }^{1}$ Centro de Ciências Agroveterinárias - Universidade do Estado de Santa Catarina - Lages, SC \\ ${ }^{2}$ Faculdade de Medicina Veterinária e Zootecnia - Universidade de São Paulo - São Paulo, SP
}

\begin{abstract}
Bacteria of the Rickettsia genus are agents of Brazilian Spotted Fever (BSF), a zoonotic disease which is difficult to diagnose, evolves quickly and can result in death. Antibodies against Rickettsia spp. in horses were studied, by means of Indirect Immunofluorescence Assay (IFAT $\geq 64$ ), in 150 blood samples taken from animals in two Santa Catarina mesoregions (Planalto Serrano and Vale do Itajaí). The overall occurrence of Rickettsia spp. antibodies in horses was $18.66 \%$, with cross-reactivity occurring in all positive samples for at least two of the species tested. Separately, according to the species, $25(16.66 \%)$ samples were positive for $R$. rickettsii, 15 (10\%) for $R$. parkeri, 22 (14.66\%) for $R$. amblyommii, 23 (15.33\%) for $R$. rhipicephali, $16(10.66 \%)$ for $R$. bellii and $19(12.66 \%)$ for $R$. felis. Only two animals resulted in a conclusive serodiagnosis, one for $R$. bellii and the other for $R$. rickettsii, at maximum dilutions of 1:4096 and 1:512, respectively. The occurrence of antibodies against Rickettsia spp. in horses from two mesoregions in the state of Santa Catarina indicates the movement of BSF agents in these sentinel animals and confirms the importance of studying spotted fever in the state of Santa Catarina.
\end{abstract}

Keywords: Brazilian spotted fever, Rickettsia spp, IFAT, horses, Santa Catarina

\section{RESUMO}

Bactérias do gênero Rickettsia são agentes da Febre Maculosa Brasileira (FMB), uma doença zoonótica, de difícil diagnóstico, rápida evolução e que pode levar o indivíduo à morte. Anticorpos contra Rickettsia spp. em equinos foram pesquisados, por meio da Reação de Imunofluorescência Indireta (RIFI $\geq 64$ ), em 150 amostras de sangue colhidas de animais em duas mesorregiões de Santa Catarina (Planalto Serrano e Vale do Itajaí). A ocorrência de anticorpos contra Rickettsia spp. observada em equinos de duas mesorregiões de Santa Catarina foi de 18,66\%, ocorrendo reações cruzadas em todas as amostras positivas para, no mínimo, duas das espécies testadas. Isoladamente, de acordo com as espécies, 25 (16,66\%) amostras foram positivas para $\mathrm{R}$. rickettsii, 15 (10\%) para R. parkeri, 22 (14,66\%) para $\mathrm{R}$. amblyommii, 23 (15,33\%) para R. rhipicephali, 16 (10,66\%) para R. bellii e 19 (12,66\%) para R. felis. Somente dois animais resultaram em um sorodiagnóstico conclusivo, um para Rickettsia bellii e outro para $\mathrm{R}$. rickettsii, nas diluições máximas de 1:4096 e 1:512, respectivamente. A ocorrência de anticorpos contra Rickettsia spp. em equinos de duas mesorregiões de Santa Catarina indica a circulação de agentes da FMB nestes animais sentinela e ratificam a importância do estudo da febre maculosa no estado de Santa Catarina.

Palavras chaves: Febre Maculosa Brasileira; Rickettsia spp.; RIFI; equinos; Santa Catarina

Recebido em 28 de março de 2012

Aceito em 7 de maio de 2013

*Autor para correspondência (corresponding author)

E-mail: a2abmv@cav.udesc.br 


\section{INTRODUCTION}

Spotted fever is a zoonotic disease that is difficult to diagnose and can be confused with other diseases. Species of bacteria of the Rickettsia genus are responsible for this human disease, which evolves rapidly and can result in death.

Rickettsiae have been diagnosed in all continents, with widespread distribution in tropical and subtropical regions. In Brazil, they have been detected in the Southeast, South and Northeast regions, but have a higher occurrence in Minas Gerais and São Paulo. In Minas Gerais, from 1981 to $2000,50 \%$ of cases of spotted fever resulted in death, constituting an epidemic in the state (Fonseca and Martins, 2007). From 1985 to 2000, a total of 47 spotted fever cases were diagnosed in São Paulo (Lima et al., 2001). Over the last ten years, 386 cases have occurred in Brazil, with 107 deaths. In Santa Catarina, the cases are isolated and mild.

In Brazil, the Spotted Fever Group Rickettsiae (SFGR) is transmitted mostly by ticks from the genus Amblyomma. A. cajennense is widespread throughout the country and is considered the main vector of Rickettsia rickettsii. According to Fonseca and Martins (2007) rickettsiae multiply in the arthropod and, in the case of $A$. cajennense, both transovarial and transestadial transmissions may occur. This allows the tick to remain infected throughout its life (transestadial) and for many generations (transovarial), acting as a vector and also as a reservoir for these bacteria in nature. Larvae and nymphs of $A$. cajennense have low host specificity and this behaviour makes ixodid ticks important transmitters of pathogens.

The participation of horses in the transmission cycle is arguable, and there is evidence that, besides carrying infected ticks, they can also act as sentinels (Sangioni et al., 2005; Freitas et al., 2009). Horses, even with no reported clinical signs and symptoms, can have high titers $(\geq 1024)$ of antibodies against $R$. rickettsii (Lemos et al., 1996) and act as vector multipliers because they are primary hosts for $A$. cajennense.

In Santa Catarina, 130 cases of the disease were reported from 2003 to 2008, mostly occurring in the municipalities of the region of Vale do Itajaí, with no recorded deaths. According to the Information System for Notifiable Diseases (SINAN), 73 cases of spotted fever were recorded between 2009 and 2011 (until August). Also in this survey, the majority of cases were recorded in Vale do Itajaí.

From the foregoing, it is clear that research needs to be done on spotted fever in the state of Santa Catarina, an objective set forth and developed in this work through studying antibodies against Rickettsia spp. in horses, sentinel animals.

\section{MATERIAL AND METHODS}

The sera samples $(n=150)$ used in this work are from the serum bank of the research project entitled "Risk factors and occurrence of antibodies against Neospora spp. in horses from the mountainous and coastal regions of the state of Santa Catarina", registered under No. 01.126/09 05/06/09 CAV/UDESC and approved by the ethics committees for animal experimentation from CAV/UDESC (Protocol 1.05.09) and for research involving humans from UDESC (Protocol 73/09, on Aug 10, 2009).

Of the 150 animals in total, 93 horses were from the Planalto Serrano, City of Lages (cared for by the Carroceiro Extension Project of CAVUDESC, from the Lages equestrian club and the cavalry of the Mounted Military Police) and 57 were animals stabled at the Camboriú equestrian club (Vale do Itajaí), situated approximately 70 $\mathrm{km}$ from the area where the majority of spotted fever cases occurred in the state of Santa Catarina (Blumenau).

The samples were sent to the Laboratory of Parasitic Diseases in the Department of Preventive Veterinary Medicine and Animal Health (VPS) at the Faculty of Veterinary Medicine and Zootechny (FMVZ), University of São Paulo (USP), where they were processed for indirect immunofluorescence using isolated rickettsiae (six species) as antigen in Brazil: $R$. rickettsii strain Taiaçu, $R$. parkeri strain At24, $R$. amblyommii strain Ac37, R. rhipicephali strain HJ5, R. bellii strain Mogi and R. felis strain Pedreira. The antigens were fixed on slides in accordance with Horta et al. (2004). Samples with titers $\geq 64$ were considered seropositive. Negative and positive control sera were used on each slide at a dilution of 1:64. The positive 
control serum was previously found to react with $R$ rickettsii, $R$. parkeri, $R$. bellii and $R$. felis, in endpoint titers of 8192, 2048, 1024 and 1024 respectively.

\section{RESULTS AND DISCUSSION}

Of the 150 equine sera, 28 (18.66\%) were positive for at least one of the species tested $(R$. rickettsi, $R$. parkeri, $R$. amblyommii, $R$. rhipicephali, $R$. bellii. and $R$. felis). Of these, five were positive for all the species. Table 1 presents the results of the positive samples and respective maximum reactive dilutions (reciprocal of titers) for each Rickettsia species.
The horses in this study did not manifest any symptoms. Although the clinical manifestation of the disease in horses is rare, animals from endemic regions of the state of São Paulo showed high titers of antibodies, as opposed to animals from non-endemic areas (Horta et al., 2004; Sangioni et al., 2005). There is also evidence, through the IFAT in horses, of the presence of $R$ rickettsii, $R$. parkeri, $R$. amblyommii, $R$. rhipicephali, $R$. bellii and $R$ felis, not only in areas where cases of spotted fever have been reported in Santa Catarina (Vale do Itajaí), but also in areas where there are no official reports of this disease.

Table 1. Reciprocal antibody titers (IFA) against Rickettsia spp. in horses from two mesorregions in the state of Santa Catarina. 2009

\begin{tabular}{ccccccc}
\hline Sample & $R$. rickettsii & $R$. parkeri & $R$. amblyommii & $R$. rhipicephali & $R$. bellii & $R$. felis \\
\hline 3 & negative & 64 & 256 & 64 & negative & 256 \\
4 & 64 & negative & negative & negative & negative & 64 \\
5 & 512 & 256 & 256 & 512 & 4096 & 128 \\
6 & 128 & negative & 128 & 64 & negative & 128 \\
7 & 128 & negative & 64 & 256 & 64 & negative \\
9 & 64 & negative & negative & 64 & negative & negative \\
14 & negative & 64 & 128 & 64 & negative & negative \\
20 & 64 & negative & 256 & 128 & negative & negative \\
21 & negative & negative & negative & negative & 64 & 128 \\
22 & 512 & 128 & 128 & 512 & 64 & 64 \\
36 & 1024 & 128 & 256 & 1024 & 1024 & negative \\
40 & 128 & negative & 128 & 64 & negative & 64 \\
47 & 256 & 512 & 128 & 64 & 256 & 64 \\
48 & 128 & 128 & 1024 & 512 & negative & 128 \\
55 & 64 & 64 & 64 & 128 & 128 & negative \\
57 & 64 & negative & negative & 64 & 64 & 128 \\
58 & 64 & negative & 128 & 128 & 64 & 128 \\
63 & 64 & 256 & 128 & negative & negative & 256 \\
64 & 2048 & 1024 & 1024 & 2048 & 1024 & 1024 \\
66 & 128 & negative & 64 & 64 & 256 & 128 \\
69 & 128 & negative & negative & negative & 64 & 128 \\
80 & 64 & negative & 128 & 128 & 64 & 128 \\
84 & 512 & 128 & 256 & 256 & negative & 64 \\
88 & 64 & negative & 64 & 128 & negative & 128 \\
125 & 512 & 128 & 64 & 128 & negative & negative \\
139 & 512 & 256 & negative & negative & 256 & negative \\
142 & 4096 & 1024 & 128 & 256 & 8192 & negative \\
143 & 2048 & 1024 & 2048 & 2048 & 4096 & 64 \\
\hline & & & & & 6 \\
\hline
\end{tabular}

Two hypotheses were considered for interpreting the results. In the first one, taking the sera individually, and not conceding the possibility of mixed infections, when an animal reacted to more than one of the rickettsiae tested (cross- reactivity), the positivity criteria established was that the higher endpoint titer separately obtained for a given species must be four times higher than the titer(s) found for the other species in that sample. Of the 28 positive sera, all were positive 
for at least two species of Rickettsia spp. Thus, only two samples resulted in a conclusive serodiagnosis (animals 5 and 125) for $R$. bellii and $R$ rickettsii at the maximum dilution of 1:4096 and 1:512, respectively.

The high incidence of cross-reactivity obtained in this study does not allow a definitive conclusion to be made as far as the species of Rickettsia spp. that mostly occur in horses in the mesorregions of the state of Santa Catarina. However, the seroreactivity observed (18.66\%) indicates that spotted fever agents may be attacking the horses evaluated, underscoring the importance of serological examinations in this species, which, along with dogs, is considered a sentinel animal for spotted fever agents.

In the second hypothesis, animals were considered positive which had antibodies (IFAT $\geq 64$ ) against each of the species of Rickettsia, taking into account that mixed infections can affect horses, which could also contribute to their importance as sentinel animals for different SFGR.

Thus, considering the importance of $R$. rickettsii in cases of spotted fever and the suggestion that $R$. parkeri, denoted as pathogenic for humans (Paddock et al., 2004), could be the species involved in the cases that occurred in Santa Catarina (Angerami et al., 2009), the equine seroreactivity for these two rickettsiae was analyzed separately.

In regards to $R$. rickettsii, recognized as the causative agent of Brazilian spotted fever (BSF), $16.6 \%(25 / 150)$ of the horses were seroreactive. Of these, $21(84 \%)$ were from the mountainous region and four (16\%) from Vale do Itajaí, more specifically the city of Camboriú. Although seropositivity for $R$. rickettsii was five times more common in horses from the mountainous region, the highest titers were noted in animals from Vale do Itajaí, with horses showing reactions at dilutions of 1:512 (four), 1:2048 (one) and 1:4096 (one). The city of Blumenau is located in this region, and along with other cities, reported cases of spotted fever every year between 2003 and 2011 (inclusive).

High titers $(\geq 1024)$ of antibodies against the other species of Rickettsia, except for R. felis, were also observed in greater proportion in animals from Vale do Itajaí, indicating the movement of SFGR among sentinel animals from this region, which corroborates the data obtained for $R$. rickettsii.

Horses, and other mammals are described as being susceptible to infection by SFGR, since studies on these animal species have demonstrated the occurrence of antibodies against Rickettsia spp. In addition, seropositive horses and dogs are often found in areas endemic for BSF (Nascimento and Schumaker, 2004). Horses are one of the main primary hosts for $A$. cajennense in Brazil (Labruna et al., 2001). This underlines the importance, when investigating the occurrence of BSF agents in a particular area, of examining the serological "status" of the local equine population, which, in this manner, acts as sentinel animals (Horta et al., 2004; Sangioni et al., 2005). The importance of vertebrate hosts, includinghorses, should also be measured when it is noted that adult ticks, even in areas endemic for BSF, have low infection rates. In the Americas, the infection rate in ticks is around $1 \%$, including areas considered endemic (Freitas et al., 2009). Thus, the influence of horses in sustaining rickettsial agents in nature should be investigated in future studies. Serological studies of infection by SFGR in horses may be of particular interest for determining the focal activity of SFGR in Brazil (Lemos et al., 1996).

In areas endemic for BSF, the seroprevalence of horses reactive to $R$. ricketsii was $77.3 \%$ (Horta et al., 2004) and $77.8 \%$ (Lemos et al., 1996). In Caratinga, Minas Gerais, 17\% (3/18) of the horse sera from an inactive outbreak of BSF, were positive for $R$. rickettsii (IFAT $\geq 1: 64$ ) (Cardoso et al., 2006), a result similar to that observed in this study. The author also suggests that, even when dealing with an inactive outbreak, seropositive horses indicate the need for surveillance in areas where cases of BSF have occurred, such as the case of the area of Vale do Itajaí in Santa Catarina.

On the other hand, in the city of Itabira, Minas Gerais, in an endemic area, Vianna et al. (2008) reported $100 \%$ infection (IFAT $\geq 1: 64$ ) in horses (11) and donkeys (three) from that locality. All the animals in this study had a reaction at a minimum dilution of 1:256. This disparity in results can be explained by the fact that in this study the area under observation was highly 
endemic for BSF and also because of the frequent contact between domestic animals, wild animals and humans.

In this study, for $R$. rickettsii, of the 25 seropositive animals, four had high titers (1024 to 4096). In Paraná, Freitas et al. (2010) observed a rate of infection of $9.33(7 / 75)$ by $R$. rickettsii in cart horses in the city of São José dos Pinhais, through the IFAT $(\geq 1: 64)$, a lower result than the one in this study. In this city, considered a non-endemic area, as well as Santa Catarina, the first human case of spotted fever in Paraná was recorded in 2005. Also in Paraná, in a non-endemic area (Almirante Tamandaré), Batista et al. (2010) found that $8.45 \%$ (6/71) of the horses were seropositive for Rickettsia spp. with titers ranging from 64 to 1024. Tamekuni et al. (2010), in northern Paraná, identified 5.5\% and $1.8 \%$ of the horses tested as positive (IFAT $\geq 1: 64)$ for $R$. rickettsii and $R$. parkeri, respectively. Likewise in Paraná, in the cities of Alvorada do Sul and Arapongas, horses seropositive for $R$. rickettsii and $R$. parkeri were identified, with the infection rates of the animals ranging from $5.6 \%$ to $55.6 \%$ (Tamekuni et al., 2011). In São Paulo, Moraes-Filho et al. (2009) identified $17.6 \%(64 / 363)$ of the horses at the Center for Zoonosis Control as seropositive for $R$. rickettsii, similar results to those noted in this study. The authors concluded that in that city $A$. cajennense is perhaps not the tick species involved in the transmission cycle to humans, when they compared their results with those from other areas endemic for BSF where horses usually have positive serology at high percentages.

In Espírito Santo (Spolidório et al., 2010), in six cities from the north of the state, $25.9 \%$ (7/27) of the horses were seropositive for at least one of the Rickettsia species tested, an intermediate value considering that in this region fatal cases of FMB in humans were recorded between 2003 and 2005.

The use of a standardized methodology (IFAT $\geq 64$ ) in the studies evaluated indicate that the different seroprevalences for Rickettsia spp. observed in horses from different regions of the country are due to the endemicity of the area under study. Thus, seroprevalence in horses can be a useful tool for a preliminary study in a particular region suspected to have FMB.
Regarding $R$. parkeri, $10 \%$ (15/150) of the horses were seropositive (IFAT $\geq 64$ ) for this species. Of these, four horses were from Vale do Itajaí and had reactions in the titrations 128 (one), 256 (one) and 1024 (two). There are few studies of seroprevalence for rickettsial species other than $R$. rickettsii. Moreover, infection by $R$. parkeri can be underestimated since the serologic studies are usually based on infections by $R$. rickettsii, and cross-reactions between these two species seem to occur frequently (Silveira et al., 2007). $R$. parkeri, considered non-pathogenic for over 60 years, has currently been documented as causing human infections in the United States (Raoult, 2004), in Brazil (Silveira et al., 2007) and in Uruguay (Conti-Diaz et al., 2009). In Espírito Santo, Spolidorio et al. (2010) identified $14.8 \%$ (4/27) of the horses as seropositive for $R$. parkeri with titers ranging from 64 to 128, lower than the values observed in the Camboriú horses. Freitas et al. (2010), in testing 75 horse sera in Paraná against $R$. parkeri did not find any seropositive animals in relation to this species. Infections by $R$. parkeri are milder in nature and do not result in death, contrary to what occurs with $R$. ricketsii. Angerami et al. (2009) compared the cases that occurred in the states of São Paulo and Santa Catarina and suggested that $R$. amblyommii or $R$ parkeri were the causative agent. $R$. parkeri was the agent found in five of the six positive samples of ticks captured in Santa Catarina with conclusive results after sequencing, being defined as $R$. parkeri strain Atlantic Forest (Medeiros et al., 2011).

The high levels of antibodies against $R$. bellii are also noteworthy, even in inconclusive cases (animals 142 and 143), which had titers up to a dilution of 1:8192, indicating its possible occurrence among horses evaluated in this study. It is a species of Rickettsia spp. that most commonly infects ticks in North America, having already been isolated from ticks of the genera Dermacentor and Amblyomma (Ogata et al., 2006). This species has already been isolated in Brazil from the ticks A. aureolatum, $A$. dubitatum, A. humerale, A. rotundatum, A. oblongoguttatum, A. scalpturatum, A. ovale and A. incisum (Labruna et al., 2004a, 2004b; Pacheco et al., 2008), from Ixodes loricatus (Horta et al., 2006) and also from Haemaphysalis juxtakochi (Labruna et al., 2007). However, its role in the pathogenesis of spotted fever is still not clearly established. Although not 
very pathogenic for experimentally infected rabbits, even when inocula are used with large amounts of the agent (Ogata et al., 2006), its role in human infections still needs to be better defined. The classification of $R$. bellii in terms of the group to which it belongs is also not clearly established. It is currently grouped in a third group since it differs phylogenetically from the species that make up the Typhus and Spotted Fever groups (Ogata et al., 2006).

Besides the high titers against $R$. bellii, in the present study, two animals (142 and 143) had positive serology for other Rickettsia spp. in high titers (up to 4096), suggesting the possibility that these animals are carriers of mixed infections. In Goiás, Martins (2009), while studying antibodies against Rickettsia spp. in humans, dogs and horses in an alleged outbreak of BSF in the city of Quirinópolis, found 10 seropositive animals for Rickettsia spp. on a property, among which four horses showing cross-reactivity between $R$. rickettsii and $R$. parkeri. This author also found a horse with cross reactivity for $R$. rickettsii, $R$. bellii and $R$. parkeri, albeit on another property studied in the region.

\section{CONCLUSION}

From the data obtained in this study, it can be concluded that the seroprevalence for Rickettsia spp. observed in horses from the two mesorregions of state of Santa Catarina was $18.66 \%$, with cross-reactions occurring in all the samples for at least two of the species tested. Only two animals resulted in a conclusive serodiagnosis for $R$. bellii and $R$. rickettsii at the maximum dilution of 1:4096 and 1:512, respectively. The occurrence of antibodies against Rickettsia spp. in horses from two mesorregions in the state of Santa Catarina indicates the movement of SFGR in sentinel animals and suggests that spotted fever may be occurring in the areas studied.

\section{ACKNOWLEDGEMENTS}

The authors express their thanks to CAPES (Coordenação de Aperfeiçoamento de Pessoal de Nível Superior) for the financial support for the publication of this article.

\section{REFERENCES}

ANGERAMI, R.N.; SILVA, A.M.R.; NASCIMENTO, E.M.M. et al. Brazilian spotted fever: two faces of a same disease? A comparative study of clinical aspects between an old and a new endemic area in Brazil. Clin. Microbiol. Inf. Dis., v.15, p.207-208, 2009.

BATISTA, F.G.; SILVA, D.M.; GREEN, K.T. et al. Serological survey of Rickettsia sp. in horses and dogs in an non-endemic area in Brazil. Rev. Bras. Parasitol. Vet., v.19, p.205-209, 2010.

CARDOSO, L.D.; FREITAS, L.N.; MAFRA, C.L. et al. Caracterização de Rickettsia spp. circulante em foco silencioso de febre maculosa brasileira no Município de Caratinga, Minas Gerais, Brasil. Cad. Saúde Pública, v.22, p.495-501, 2006.

CONTI-DIAZ, I.A.; MORAES-FILHO, J.; PACHECO, R.C. et al. Serological evidence of Rickettsia parkeri as the etiological agent of rickettsiosis in Uruguay. Rev. Inst. Med. Trop. São Paulo, v.51, p.337-339, 2009.

FONSECA, L.M.; MARTINS, A.V. Febre maculosa: Revisão de literatura - Artigo Revisão. Saúde \& Ambiente Rev., v.2, p.1-20, 2007.

FREITAS, M.O.; MOLENTO, M.B.; BIONDO, A.W. et al. Febre Maculosa: Primeiros Relatos do Paraná, 2009. Disponível em: <http://www.crmvpr.org.br/?p=imprensa/artigo_detalhes\&id=55>.

Acessado em: 20 jul. 2009.

FREITAS, M.C.D.O.; GRYCAJUK, M.; MOLENTO, M.B. et al. Brazilian spotted fever in cart horses in a non-endemic area in Southern Brazil. Rev. Bras. Parasitol. Vet., v.19, p.130-131, 2010.

HORTA, M.C.; LABRUNA, M.B.; SANGIONI, L.A. et al. Prevalence of antibodies to spotted fever group rickettsiae in humans and domestic animals in a brazilian spotted fever endemic area in the state of São Paulo, Brazil: serological evidence for infection by Rickettsia rickettsii and another spotted fever group rickettsia. Am. J. Trop. Med. Hyg., v.71, p.93-97, 2004.

HORTA, M.C.; PINTER, A.; SCHUMAKER, T.T. et al. Natural infection, transovarial transmission, and transstadial survival of Rickettsia bellii in the Tick Ixodes loricatus (Acari: Ixodidae) from Brazil. Ann. N. Y. Acad. Sci., v.1078, p.285-290, 2006.

LABRUNA, M.B.; KERBER, C.E.; FERREIRA, F. et al. Risk factors to tick infestations and their occurrence on horses in the state of São Paulo, Brazil. Vet. Parasitol., v.97, p.1-14, 2001. 
LABRUNA, M.B.; WHITWORTH, T.; BOUYER, D.H. et al. Rickettisia Belli and Rickettsia amblyommii in Amblyomma ticks from the state of Rondônia, Western Amazon, Brazil. J. Med. Entomol., v.41, p.1073-1081, 2004a.

LABRUNA, M.B.; WHITWORTH, T.; HORTA, M.C. et al. Rickettsia species infecting Amblyomma cooperi ticks from an Area in the State of São Paulo, Brazil, where Brazilian Spotted Fever is endemic. $J$. Clin. Microbiol., v.42, p.90-98, 2004b.

LABRUNA, M.B.; PACHECO, R.C.; RICHTZENHAIN, L.J. et al. Isolation of Rickettsia rhipicephali and Rickettsia bellii from Haemaphysalis juxtakochi ticks in the State of São Paulo, Brazil. Appl. Environ. Microbiol., v.73, p.869-873, 2007.

LEMOS, E.R.S.; MACHADO, R.D.; COURA, J.R. et al. Epidemiological aspects of the Brazilian Spotted Fever: serological survey of dogs and horses in a endemic area in the state of São Paulo, Brazil. Rev. Inst. Med. Trop. São Paulo, v.38, p.427-430, 1996.

LIMA, V.L.C.; SOUZA, S.A.L.; SOUZA, C.E. et al. Situação da febre maculosa na região administrativa de Campinas - SP. In: SIMPÓSIO DE DOENÇAS TRANSMITIDAS POR CARRAPATOS, 1., 2001, Campinas. Anais...Campinas: 2001. (Resumo)

MARTINS, M.E.P. Aspecto epidemiológico da febre maculosa no município de Quirinópolis, Goiás, Brasil. 2009. 96f. Tese (Doutorado em Ciência Animal) Universidade Federal de Goiás, Goiânia.

MEDEIROS, A.P.; SOUZA, A.P.; MOURA, A.B. et al. Spotted fever group Rickettsia infecting ticks (Acari: Ixodidae) in the state of Santa Catarina, Brazil. Mem. Inst. Oswaldo Cruz, v.106, p.926-930, 2011.

MORAES-FILHO, J.; HORTA, M.C.; PACHECO, R.C. et al. Pesquisa de anticorpos anti-Rickettsia rickettsii em eqüinos do Centro de Controle de Zoonoses do município de São Paulo (CCZ/SP). Brazilian J. Vet. Res. An. Sci., v.46, p.85-91, 2009.

NASCIMENTO, E.M.M.; SCHUMAKER, T.T.S. Isolamento e identificação de riquetsias no Brasil. Rev. Bras. Parasitol. Vet., v.13, p.193-196, 2004.
OGATA, H.; SCOLA, B.L.; AUDIC, S. et al. Genome sequence of Rickettsia belli illuminates the role of amoebae in gene exchanges between intracellular pathogens. PLoS Genetics. v.2, p.76, 2006.

PACHECO, R.C.; ROSA, S.; RICHTZENHAIN, L. et al. Isolation of Rickettsia bellii from Amblyomma ovale and Amblyomma incisum ticks from southern Brazil. Rev. MVZ Córdoba, v.13, p.1273-1279, 2008.

PADDOCK, C.D.; SUMMER, J.W.; COMER, J.A. et al. Rickettsia parkeri: a newly recognized cause of spotted fever rickettsiosis in the United States. Clin. Infect. Dis., v.38, p.805-811, 2004.

RAOULT, D. A new tick-bornerickettsiosis in the USA. Clin. Infect. Dis., v.38, p.812-813, 2004.

SANGIONI, L.A.; HORTA, M.C.; VIANNA, M.C.B. et al. Ricketsial infection in animals and brazilian spotted fever endemicity. Emerg. Infect. Dis., v.11, p.265-269, 2005.

SILVEIRA, I.; PACHECO, R.C.; SZABÓ, M.P.J. et al. Rickettsia parkeri in Brazil. Emerg. Infect. Dis., v.13, p.1111-1113, 2007.

SPOLIDORIO, M.G.; LABRUNA, M.B.; MACHADO, R.Z. et al. Survey for Tick-Borne Zoonoses in the State of Espirito Santo, Southeastern Brazil. Am. J. Trop. Med. Hyg., v.83, p.201-206, 2010.

TAMEKUNI, K.; TOLEDO, R.S.; SILVA FILHO, M.F. et al. Serosurvey of antibodies against spotted fever group Rickettsia spp. in horse farms in Northern Paraná, Brazil. Rev. Bras. Parasitol. Vet., v.19, p.259$261,2010$.

TAMEKUNI, K; TOLEDO, R.S.; SILVA FILHO, M.F. et al. Survey of rickettsiae in humans, dogs, horses, and ticks in Northern Paraná, Brazil. Semina: Cien. Agr., v.32, p.1527-1538, 2011.

VIANNA, M.C.; HORTA, M.C.; SANGIONI, L.A. et $a l$. Rickettsiose do grupo da febre maculosa na Vila de Capoeirão, Itabira, Minas Gerais, Brasil. Rev. Inst. Med. Trop. São Paulo, v.50, p.297-301, 2008. 